\title{
DESIGN STRATEGY FOR STATE ISLAMIC UNIVERSITIES (PTKIN) TOWARDS SCIENCE AND TECHNOLOGY DEVELOPMENT IN INDONESIA
}

\begin{abstract}
Abdul Fattah*
Abstract: One of the issues most discussed in the arena of contemporary Muslim thought in the last few decades is about Islam and science. Muslim intellectuals provide diverse responses to these issues, particularly associated with the character of modern science and technology. Some people regard science and technology as something neutral and universal. While others assess the science and technology is not neutral, depending on its creator. Therefore, Muslims must be careful with science and technology from the West. Noteworthy together is a contemporary Muslim scholar realized that the only way to drink in the glory (golden age) of Muslims is through the mastery of science and technology. In terms of locality Indonesia, the expectations of many lay on the State Islamic Universities (UIN, IAIN, and STAIN), especially in the framework of the integration between Islam and science and to eliminate the dichotomy of science that has made Muslims excluded from the global science and technology arena.
\end{abstract}

Keywords: PTKIN, science and technology, Western civilization, contemporary Muslim thought, culture strategy.

\section{Preface}

Tslamic discourse and development or the development of science and technology is one of the themes most dealt with in 1 the last few decades. This discussion revolves around the two crucial issues, namely first how to tackle the downturn and the backwardness of Muslims in the field of science and technology,

* Jurusan Pendidikan Agama Islam Fakultas Ilmu Tarbiyah dan Keguruan IAIN Mataram. Email: fath_smart@yahoo.com. 
and secondly how to behave toward modern science is a product of Western civilization. Indeed, these two issues can be elaborated further in the context of Indonesia into how the role and contribution of the State Islamic Universities for development and science and technology development in Indonesia? Of course it would be naive if we only expect a lot at College of Religious Islamic State, while on the other hand many important components such as managerial aspects, financing (see Esposito, 2001:100), human resources, support the community, the attention of government (or indeed political will), and so forth that do not support the role and functions of Education high State Islamic Religious fullest. However, as an institution of higher education, at least the State Islamic Universities (especially UIN, IAIN and STAIN) has great potential for planting awareness of the importance of promoting the dignity of the nation by improving the quality of science and technology-based religious values. So that Indonesia is not only a country to borrow a phrase Jeffrey Sachts (an economist at Harvard University-USA) in the category "technological excluded" that the consumer countries only technology into the market place (exactly colony) technology without being able to compete with developed countries such as United States, most European countries, and Japan (Yakin, 2008:1).

In practice, the discussion of the above three things are often intertwined and inseparable. When talking about the backwardness of Muslims in the field of science and technology, at the same time can also be certain to discuss the progress and achievements of science by Western civilization, as well as attitudes toward Muslims, and vice versa. At its peak, appeared intent to look at the contribution of universities in the attitude, at least that was driven by the College of Islamic Religious Affairs in the Indonesian context.

On development, the response of the contemporary Muslim intellectuals who took part in the debate is extremely diverse. It is part of a large flow of thought Muslims after the defeat of the Arabs by Israel in 1967, which gave birth to self-criticism and the 
next be the starting point for a welcome revival of the Islamic world (Islamic Resurgence), namely how to behave towards tradition (Turath) and modernity (Hadâtsah). Certainly one of the products of modernity is a science and technology.

In fact, discussions about Islam and science involve a lot of intellectuals from various countries, such as Malaysia, Pakistan, the UK, North America, Egypt, and Indonesia. Not only in terms of the level of discourse, this debate is reaching the level of praxis. Birth of various academic disciplines such as Islamic economics, Islamic psychology, sociology of Islam, Islamic studies, and so is part of the product the debate. Muslim intellectual restlessness reality backwardness of Muslims in many aspects of life that stems from issues of science, has encouraged them to be actively involved both in its theoretical and practical discussion about Islam and science.

This paper will elaborate the map in response to Muslim thinkers of modern science is a product of Western civilization. Specifically, this paper will conclude with a discussion of the role of the State Islamic Universities (PTKIN) in the development or the development of science and technology in Indonesia. To better understand the problem, before it will be presented briefly the condition of adversity people after they've become a "Beacon" for several centuries, then move to the West. Images of the painful condition will be accompanied by the identification of a number of factors and the possibility of finding a solution.

\section{Islam and Revolution of Science and Technology: Historical Survey}

In a long period of time, the Muslims never display a spectacular building in the history of civilization. Pioneering civilization momentum and is growing rapidly in the reign of the Umayyads (41 H / $132 \mathrm{H}$ up to $661 \mathrm{AD} / 750 \mathrm{AD}$ ), and culminated in the reign of the Abbasid Dynasty $(132 \mathrm{H} / 656 \mathrm{H}$ up to $750 \mathrm{AD} / 1258 \mathrm{AD}$ ). While at the same time, the West (or indeed Europeans) actually are living in an atmosphere of darkness 
(Dark Age), where the intellectual dynamics at all is a strange thing (Umam, 2001:3).

Grow in Islam during the period of the so-called Harun Nasution as "Carnal Knowledge". The development is preceded by the translation of books from Greek into Arabic, based in Bayt alHikmah in Baghdad. Sciences covered translation movement is medicine, mathematics, physics, mechanics, botanical, optics, astronomy, in addition to philosophy and logic. Which is translated essays and Studios, Hippocrates, Ptolemy, Euclid, Plato, Aristotle, and others (Nasution, 1996:298-299).

Intellectuals and scholars of Islam's golden age is not only a master of science and philosophy that they derive from the classical Greek civilization, but they have developed and added to the results of their own investigations in the field of science and the results of their thinking in the field of philosophy. Thus, there arises scientists and philosophers of Islam, in addition to scholars in religious studies. For the development of sciences was established universities. The famous among them is the University of Cordoba in Andalusia (Islamic Spain), University of Al-Azhar in Cairo and the University Nizamiyah in Baghdad. At the University of Cordoba participating include the Christian people of other European countries (Hitti, 1964:530).

Based on this reality, the Islamic world at that time known by its scientists who master a variety of scientific disciplines, for example in the field of theology, there are al-Ash'ari (d. 935) and alMaturidi (d. 944), in the field of literature such as al- Jahiz (d. 780) and Ibn Qutaybah (d. 828), in the field of history and geography was al-Baladhuri (d. 820) and al Ya'qub (d. 897), in Sufism there are al-Muhasibi (d. 857), Bayazid-Bustami (d. 875), and al-Hallaj (d. 922), in the medical field such as al-Razi (d. 923-32) and Ibn Sina (d. 1037), in mathematics and astronomy as Muhammad ibn Musa al-Khwarizmi (d. after 846) and Ibn Haytham (d.1039), and in philosophy there are al-Kindi, al-Farabi (d. 870), Ibn Sina (d. 980), and others. They are among the scientists that marked the heyday of Muslim civilization. 
Not only within the scope of religious knowledge and some discipline, as mentioned above, the natural sciences Islamic scholars leaving various magnum opus in zoology, botany, anthropology, and geology. Al-Jahiz in his book "Al-Hayyawân", according Hitti, talk about the evolution and anthropology (Hitti, 1964:382). Ikhwan al-Safa 'in Rasâil explained that the mineral kingdom, plant kingdom, animal nature, and human nature is a dial-connect rounds. Natural mineral advance there, long before the natural vegetation. After a new plant there is a natural animal, marine animals before land animals, and animals for centuries before there were human beings. At the height of the animal nature, there are things that a lot of similarities in form and behavior to humans (Sharif, 1963:303-304). Ibn Maskawaih have the same theory. Evolution of natural mineral natural herbs to occur through the beads, of natural vegetation natural to the animal through the palm trees and the nature of animals into human nature through apes. Mas'udi also call the theory of evolution in his book Al-Tanbih. On that basis, Dieterici authored a book with the title of Darwinism in the Tenth Century and Nineteenth (Landau, 1962:56).

The effect of nicks glories of civilization in about the seventh (VII) century until the Thirteenth (XIII) century AD, still felt strong in Europe, and even up to a few centuries later. In centuries known as the golden age of Islam, the Muslim world to be a beacon of civilization and science pioneer brilliance. Muslim civilization was a referral from people other people. Arabic became the international language of scientific fields, which must be mastered by those who want to explore the field on this one. At the same time, a variety of new vocabularies add vocabulary European languages. This can be exemplified in the word "chiffre" (France), "chipper" (Britain), "iiffer" (Germany), as well as the word "zero" (France, UK), everything is a loan word from the Arabic word "sifr" meaning "blank". Likewise some English words derived from Arabic as admiral, barque (barracks), cable, or shallop or sloop, and monsoon (monsoons). According to Jacques C. Risler, Arabic 
numerals came to Europe was brought by an Italian from North Africa in 1202 AD (See Watt, 1994:21; Hitty, n.d.: 177; Risler, 1955:161).

It is worth noting that advances in science are achieved by Muslims for centuries it was obtained through a strong effort with the motivation that is driven by religion. Precisely according to Harun Nasution, a high position in the sense that the Qur'an and hadith and rational theology adopted by the majority of Muslims, brought to arise and develop rational thought and knowledge among Islamic scholars classical age who have a major influence in the emergence of the Renaissance in Europe Middle Ages and the development of modern European civilization as witnessed today (Nasution, 1996:303).

In addition, the synergy is good between the rulers (government) with scientists along with their scientific tradition or culture of science is very strong to make a remarkable achievement of the nation backward (Arab Bedouin) and have never been taken into account in the constellation of civilization became the leader of civilization and give very valuable contribution in scientific fields such as astronomy, mathematics, chemistry, physics, to philosophy, which later became a milestone and achievement of science in today's modern world.

Several centuries were at the peak of world civilization, the Muslims entered a phase of decline, including in the field of science and technology. The tragic fate befell the people who've led this civilization. They suffered humiliation and oppression of the occupation. Poverty and ignorance to be something attached to it. Nurcholish Madjid never provides an illustration of the sad reality of this people, saying:

Today the Islamic world practically is the most underdeveloped region of the earth between the adherents of the major religions. Islamic countries are far behind from Northern Europe, North America, Australia and New Zealand were Protestant; Southern Europe and South America are Roman Catholic; Orthodox Catholic Eastern Europe; Israel is Jewish; Hindu India; China (giant dragon), South Korea, Taiwan, Hong Kong and Singapore (little dragon) that Budhist-Confucianism; Japanese Buddhist Taoist; and 
Thailand were Budhist. Practically none of the major religions on earth is lower advances in science and technology (science) it rather than Islam. In other words, of all the major faiths in the world, the followers of Islam is the most low and weak in terms of science and technology. (Madjid, 1997:21-2)

The developments portrait in science (science) in the Muslim world also presented very interesting in the most prestigious science journal Nature, 2nd November 2006. The report is divided into nine sections that present the data brief development of science world since the days of the Abbasid caliphate based in Baghdad to Bani Ottomans in Istanbul. At that time, Europe was still very backward in terms of science and technology. That's a fact.

Also discussed contemporary views about the development of scientific research in Islamic countries today. Mentioned in the report, the development of science in the Islamic world is uneven progress. Islamic countries in North Africa is still struggling with problems of poverty and social and economic problems that do not show progress in science. While in the Gulf countries are rich in oil, apparently a blessing petrodollars do not necessarily generate scientific research. Gulf countries are considered to be advanced in science is represented by Iran's nuclear research projects and military weaponry. As for Turkey, the only member of the Organization of the Islamic conference (OIC) are also members of the European Union, spurred himself in scientific research because they want to align themselves with the people of Europe to another. In the Asian subcontinent, Pakistan is also a pioneer in scientific research, especially in nuclear weapons. Outside of these countries, there is no clarity about the science project / science and technology that are being launched, let alone realized.

Admittedly there are a number of Muslim countries considered relatively advanced in science and technology development, but generally concluded that Muslim countries do not have a great concern to the development of science. Even the budget for research and development are very low when compared to the 
average global budget. In addition, research data held on the 57 Muslim countries who are members of the organization of Islamic Conference (OIC) is also unclear and inaccurate. Stated clearly:

"Stretching from Indonesia to Morocco and from Uganda to Kazakhstan, countries with large Muslim populations are home to some 1.3 billion people. The Islamic world encompasses remarkable diversity in political systems, geography, history, language and culture. But science in these nations is weak, with spending on research and development far lower than the global average. The official statistics database of the Organization of the Islamic Conference (OIC) reveals information on each of the 57 OIC nations on everything from arable land per tractor to Internet users, but you won't find any data on research. Science indicators for OIC countries are also scarce among data collected by the World Bank and United Nations agencies - largely a reflection of many of these countries' low level of interest in science." ( (www.nature.com. taken on 1st Februari 2007)

Ironically, the reality is happening in Muslim countries is very much different, for example with the achievements of the Jewish people. This nation has a great attention to science. According to statistics, the ratio of the Jewish population by the number of them hold doctoral scientists in various disciplines is the largest in the world, 1 million versus 16.000 and his scientists have been awarded the Nobel Prize 161. It was startling.

\section{The Glory of Western Civilization: A Revolutionary Change}

In parallel to the decline in the Muslim world, the West is slowly building a civilization through a series of revolutionary changes such as the revolution of science, the French revolution, the industrial revolution, the professionalization of science, the interaction of the meeting between science and technology, and the revolutions of the twentieth century in the science of sustainable affecting not only Western world itself, but also the entire world.

In the analysis of Cemil Akdogan, a Professor of History of Science at ISTAC-IIUM, mastery in the field of science is the true secret of Western progress. He is an abstract work that later bear fruit in technological capabilities. Wrongly identifying the Islamic nations of Western civilization with technology tools such as 
vehicles, power tools, televisions, radios, telephones, airplanes, nuclear weapons, and so on, then try to imitate it in the end hurt yourself. The ability of Western technology is the application of scientific knowledge. Without mastery of the scientific basis, only producing devices technology through imitation is very risky. Muslim nations according to him, will never take over the scientific leadership of the West, Western supremacy in science-based technologies will continue (Akdogan, 2005:93-94).

In the threshold of dominance of Western civilization, awareness of people burst inside backwardness of Muslim intellectuals. Weak mastery of the science is the key of this lag. Thinkers such as Muhammad Abduh, Seyyed Hossein Nasr, Fazlur Rahman, Ismail Raji al-Faruqi, Syed Muhammad Naquib al-Attas, and Ziauddin Sardar is among those who are concerned and very eager in seeking a solution backwardness of Muslims in this one.

According to Muhammad Abduh, who is regarded as one of the icons reformer of Islam in the modern age, stating that the backwardness of Muslims in the field of science is the result of the static attitude to them. According to him:

"... In the teachings of Islam is filled with the spirit that inspires science. Backwardness of Muslims is more because of their attitude static (oldfashioned). Religion always walked side by side with reason to wade through oceans science, exploring the earth's surface and rising into the sky high, to investigate the signs of Allah and the secret of his creation. When religious ideas and the prosecution freeze-prosecutor science has not been active, then even then helped freeze anyway. " (Abduh, 1978:121)

Not only introspect on the backwardness of science in the Muslim world, the contemporary Muslim thinkers have diverse views on modern science is a product of the West. On the one hand there is a group who worshiped him as such, and requires Muslims to imitate the West, if also want to move forward, on the other hand, appeared a group of scientists who are critical of the West, by stating that Western science besides having contributed in advancing the world, at the same time each also has a major role in the birth of various problems and humanitarian crisis of modern man. This happens due to neglect of the sacred (God) and his 
refusal to revelation as a source of knowledge. Here, the role of Muslims then required to take back the power in place of civilization, so that the knowledge generated will actually provide serious benefits, not only for Muslims in particular, but also humanity as a whole.

\section{The Reactions of Contemporary Muslim Thinkers on Science and Technology}

The important question that should be raised right now, how can Muslim thinkers to respond to the backwardness of Muslims and the dominance of Western science? As part of the effort to retake the supremacy of science, there are many variants of Muslim thinkers who talk about it, but in general based on the orientation of his thinking, can be grouped in three major groups namely; First, affirmative-apologetics group; The second group of instrumentalists, and Third, the critical group. The following assumptions and arguments described each in detail.

\section{The Affirmative- Apologetics Group}

Basically, this group assumes that Islam is a doctrine that has been completely and talks about all things, science. Al-Qur'an which is the main reference in Islam has been covering all fields of science. With this assumption, all the Western scientific discoveries that are basically already exist in the Qur'an. In a more concrete form, this group seeks to affirm or justify these discoveries with verses of the Qur'an.

One of thinker who belongs to this category, namely Maurice Bucaille. With his work The Origin of Man According to the Bible, the Qur'an and Science (1988), Bucaille, which is the French surgeon, tried to fit between the Qur'an with modern scientific discoveries and his work was very well-known and best-seller in the country Muslim-state.

Bucaille method is basically simple. He asked his readers to ponder some of the verses of the Qur'an. Of the various terms that can be given verse, he pulled one that fits the scientific facts. He 
then concluded that, if the Bible is often wrong in describing natural phenomena, then the Qur'an is always correct and appropriately anticipate all the great discoveries of modern science.

To achieve this, he composed a number of references in the Qur'an that impressive about bees, spiders, birds, herbs and various vegetables, dairy animals, embryos, and human reproduction. Discussion of inanimate objects ranging from the planets of the solar system, galaxy and interstellar matter, to the expansion of the universe, and the conquest of space. He ended the discussion of each issue with an amazing conclusion that the suitability of the revelations of the Qur'an with scientific facts as proof of the nature of the miracles of the Qur'an (Bucaille, 1998:52).

The method used by Buccaille is very famous, often referred as Buccaillisme. For many Muslims, with a glass of adversity and their inferiority in the fields of science, what Buccaille did can satisfy their psychology, and make them calm dealing with the supremacy of Western Christian civilization.

Notably, for while other Muslim thinker, what did by Buccaille could be dangerous. Pervez Hoodbhoy, a physicist from Pakistan, for example states that for those who believe and understanding, there are at least two fundamental flaws of this Buccaille methodology: First, proof of a proposition will only be meaningful if the possibility was also revealed unprovability preposition. What does it mean we assume that the number of angle triangle is equal to 180 degrees, and then we prove it. The believers know that in all things Qur'an impossible one, since the beginning of all the effort of proving the nature of revelation already fully right from the start.

Secondly, it is very dangerous to hang an eternal truth in the theory of science that may change. Our understanding of the universe can change dramatically over time. And science does not hesitate to leave his old theories and supporting new ones. Would not it be a disaster if someone was trying to moor theological ideas on this drifting sand (Hoodbhoy, 1991:123-124). 
On that basis, equating the revelation that is sacred and has the absolute truth with scientific findings that the nature of relative truth would be problematic when justified scientific findings are then considered irrelevant and revised with new findings. As a result, the truth of revelation as a "justification" will also be able to participate immediately be reduced.

\section{Instrumentalist Group}

In fact, this group holds that science or science is simply a tool, and is not tied to specific values or religion. Science according to their neutral and universal. He can be likened to a knife. Good or bad depending on the user. For mothers, the knife can be used for cutting vegetables or fruit peel, but for a civilian knife is a powerful weapon to injure others.

With this assumption, then the only way to catch up Muslims, namely by transferring knowledge and technology from the West to the Islamic world. Sayid Jamaluddin al-Afghani (1838-1897) is one of the characters, who, though known to be very antiimperialism, but greatly admired the achievement of western science. He saw no contradiction between Islam and science. According to him, the West is able to colonize the Muslim world because it has science and technology, therefore the Muslims should also master it in order to fight against Western imperialism (Bagir, 2002:138). The idea of al-Afghani is quite popular in the Islamic world. Main successor idea of al-Afghani is the famous Muhammad Abduh (1849-1905) and Muhammad Rashid Rida (1865-1935). Both had visited several European countries and was very impressed with their experience there. For Abduh and Rida, modern science is good; the problem is its aim.

Other thinker who believes this instrumentalist can be found in the figure of Fazlur Rahman. He said that science is basically good, that makes it worse is its misuse. But the decision to abuse does not depend on science itself, but on a moral priority. Muslims, according to Rahman, it should not bother to make a plan and 
outline how to create an Islamic science (Rahman, 1988:3-11; 1992:68-72).

The instrumentalist views who assumes knowledge that neutral is then criticized for being loud in the midst of the notion that civilization and Western science is loaded with values and interests of the West, is destructive to humanity and cannot meet the needs of material, cultural and spiritual human beings.

\section{Critical Groups}

In contrast to the spirit of the instrumentalists who see neutrality of science. The group assessed the science nothing is neutral, but always refract from the value of the constituent. it is the group that holds critical of modern science Western products. Indeed their criticality it is also widely supported by the opinion of Western scientists themselves to the development of science prevailing in the West. As for the Muslim thinkers involved in this case, generally a thinker who live in the West, or at least a graduate from one of the famous universities in the West.

In this case, Seyyed Hossein Nasr, for example, expressed concern over the secular nature of modern science does not acknowledge the fact that he considered divine and its position as a source of knowledge. Modern science says had oppressing epistemology by means not recognizing means another view of the nature, including those in the religion. Belief in the reality beyond the empirical reality is only regarded as a myth or superstition (Nasr, 1989:33).

Losing the sacred aspects, as stated by C.A. Qadir has resulted in alienation and separation in the life of modern man. There is an imbalance and order. The human soul experiencing spiritual schizophrenia disease, which has no way out except to go back to the Source Primordial and revive this sacred aspect (Qadir, 1988:5). Meanwhile Ziauddin Sardar reject negative impact solutions with the addition of Western science Islamic ethics. According to him, this argument is not valid due to the impact of modern science also 
comes to cognitive epistemology that formulation is also required (Sardar, 1989:70).

Critics of the concept of Western science is also expressed by Naquib Al-Attas who thinks more cause problems and errors than childbirth harmony, kindness, and justice. Western science he has lost the ultimate destination because it is not digested fairly. As a result it brings chaos in human life and instead of peace and justice. Studies that seems right but more productive towards error and skepticism, science for the first time in history, bringing chaos to the contents of the universe; animals, plants, and metals (al-Attas, 1978:217).

More systematically, this critical group then convey an idea called Islamization of science, and was declared as the best option for efforts to rebuild the superiority of Muslims in science without having uprooted from their Islamic values. This movement is emerging towards the end of the 1970s and remained in existence until now. The idea is conceptually Islamization of science stems from al-Attas. She had given birth to his ideas on the trial of education is very important in the history of contemporary Islam, the Islamic Education First Trial throughout the world in Mecca in 1977. The trial was attended by no less than 313 Islamic scholars and thinkers from around the world. In this forum al-Attas submit a working paper entitled Preliminary Thoughts on the Nature of Knowledge and the Definition and Aims of Education, which examines the nature of science is not neutral and Islamization sciences. This idea was further perfected again with the publication of the book The Concept of Education in Islam: A Framework for an Islamic Philosophy of Education, in addition to the books that have been published previously titled Islam and Secularism.

In its development, the idea of Islamization of science is experiencing significant growth, and gave birth to variants of interpretation. However, the general assumption was developed by the initiators of this idea that modern science is a product of Western scientists, not value-free and loaded with the worldview of the Formulator. Therefore Muslims cannot simply transfer the 
knowledge and technology produced by the West, but it should do the filtering first, and give the values of Islam to them.

\section{The Creative Potential of the State Islamic Universities (PTKIN) in the Development of Science and Technology in Indonesia: Efforts to Spur the Self}

After making the pilgrimage intellectual (historical) to the dynamics of civilization and science and technology revolution in the Islamic world, complete with its destruction, the various entities of the principal causes deterioration needs to be addressed wisely. wisdom and approach of course adjusted to the locality of Muslims. That's in line with the phrase that states; think globally act locally. In the Indonesian context, the authors looked at the College of Islamic Religious Affairs has great potential and contribute to the realization of such omission, plus the appearance of concrete solutions that can be taken together. Of course everything is done with the mirror to the past glories and tragedies of Muslims (as described above).

According to the experts, there are several global powers who wish to form a future world, namely: (1) the progress of science and technology in the field of information and new innovations in the technologies that facilitate human life; (2) free trade supported by advances in science and technology; (3) regional and international cooperation for bringing the life of nations sought regardless of national borders; and (4) increasing awareness of human rights and human responsibility in a common life, and the increasing awareness together in a democracy (Tilaar, 2000:15).

In view of Muhaimin, various global powers underlines the necessity of the State Islamic Universities, in particular UIN/IAIN/STAIN, to prepare prospective graduates who excel in science and technology, productive, and competitive, while awareness of their rights and obligations in a common life and mutual awareness democratic in nature (Muhaimin, 2004:270).

In connection with these problems, normatively, in Islam there is a universal one, that: (1) God will raise the degree (high) against 
those who believe and bookish knowledge (Surah al-Mujadalah: 11); (2) Islam is a religion that teaches "work orientation" (achievement orientation) (Surah al-Kahf: 110), as also expressed in the saying that "the award of Ignorance by descent, while the award in Islam is based charity"; (3) a high or low degree of the Pious person is also determined by the performance or quality of good deeds as the actualization of the potential of faith (Surah alHujurat: 13); (4) human beings should be respected as a human being regardless of the color of his skin, wherever it came from, whatever their religion, to the extent that any angel in his honor (Surah al-Baqarah: 34); (5) man given their fundamental rights, namely the right to life (Surah al-An'am: 151), the right to equality (Surah al-Hujurat: 13), the rights to justice (al-Ma'idah: 288), the right protection of property (Surah al-Baqarah: 188), and the right to freedom of religion (Surah al-Baqarah: 256).

For the realization of these normative view to building human resources in Indonesia sound science and technology, mainly driven by the State Islamic Universities (PTKIN) in Indonesia, the necessary strategic steps called by Syarif Hidayat as "cultural strategy". The strategy includes; first, instill a love of science and technology in order to develop a culture of science and technology. Science and technology culture should ideally be a breath of life and become part of Indonesian culture in order to successfully navigate the era of industrialization and globalization. In this context, education is a powerful vehicle for the cultivation of science and technology. In this case, the mastery of students in science, mathematics, and foreign languages (including English) is extremely important, because the third is a provision of the material basis for the development of science and technology. Weakness in the art should soon be overcome by growing interest in and passion for studying the science that is often seen as irrelevant to the needs of everyday life. What is learned as alien and alienated (Syarief, 1999:6).

Therefore, methods of teaching and learning should be made attractive and fun. Students need to be brought closer to nature 
and life, because all phenomena and what is contained in nature is the source of knowledge. To the students need to be instilled in the consciousness that the actual creation of the heavens and earth science contained an extremely broad as signs of God's power. Thus, a love of science will be accompanied by the belief in the omnipotence of God so that it becomes the main capital in the formation of human science and technology and immoral.

Second, create the atmosphere and the learning process can generate and foster creativity, innovation, interest, and enthusiasm for learning. Learners in the College of Islamic Religious Affairs in particular, are encouraged to always ask and dare to express opinions. Ideally pleasant learning atmosphere, so as to encourage the growth of motivation, interest, and enthusiasm for learning and the development of student creativity. The process of learning is the main capital to an innovation and innovation is a source of technological mastery. The spirit and passion of university students studying Islamic Religious Affairs must be grown, so that learning becomes a necessity. Furthermore, interest in reading and writting habits also need to be nurtured, because with that science will continue to evolve (Syarief, 1999:6-7).

Third, develop willpower (fighting spirit), professionalism, and excellence insights. Professionalism and insight excellence are the keywords that need to be echoed in an effort to build a quality human resources in facing the era of industrialization and globalization. To that end, students at the State Islamic Universities need to get used to a better result and do not work carelessly. Simultaneously, the unyielding attitude when having difficulties should constantly implanted. Thus, the power struggle will become a part of life attitude, character, and personality. Values like that are also able to foster entrepreneurial spirit and self-reliance. Graduates (output) the State Islamic Universities-minded as it would be able to live their lives and the lives of the brave, is also ready to open up employment opportunities and businesses (Syarief, 1999:7).

Fourth, develop an attitude of life-saving, precise, meticulous, orderly, diligent, and disciplined. Those values are basic values that 
must be embedded within each student of the State Islamic Universities, because it is indispensable in any age, especially in the era of modernization. The basic values as it was no less important than instrumental values such as professionalism and culture of science and technology. Therefore, the cultivation of basic values must be one of the main missions of the educational process, especially organized College of Islamic Religious Affairs (Syarief, 1999:7).

Fifth, to develop moral and noble character as the embodiment of faith and devotion to The Almighty God. This is also the basic values are very important to the era of modernization and globalization. Through the teaching-learning process in the College of Islamic Religious Affairs, moral values and noble character always instilled absolute. Not just touching the cognitive aspects, but also should touch the affective and psychomotor aspects, so sublime moral and character to be a part of the character and personality of university students of Islamic Religious Affairs (Syarief, 1999:7).

Hidayat Syarief refers to the five strategies above as "cultural strategy" that needs to be used as a foundation in building the education system of the State Islamic Universities tough, so it can produce a human Indonesia with competitiveness and high fighting spirit; sound science and technology, morality, and culture as a fundamental principle of morality and justice. On the foundation that the education system in the State Islamic Universities built with pillars that will be in favor of it, namely; (A) learning how to know; (B) learning how to do; (C) learning how to live together; and (d) learning how to be.

In line with the culture of the above, an indicator of the success of university students of Islamic Religious Affairs in the learning process that leads and supports the development of science and technology is minimal includes four categories, namely; first, implement the teachings of the Qur'an and the Hadith related to maximizing the potential of a mind that had blown her spirit by Allah. In a further analysis of Harun Nasution, for implementing 
the teachings of the Holy Qur'an, the Hadith mentioned above, the scholars of the Classical Era to develop the science of religion by using Ijtihad and develop science which is now called "science" by studying and mastering science and Greek philosophy there is in the Middle East in their day (Nasution, 1996:392).

Second, the study tempestuous spirit, not just the religious knowledge but knowledge that there are obtained from China or other developed countries (as a representation of the general science), although they are not a Muslim majority. Third, jihad and Ijtibad seek knowledge is placed not only in the sphere of "justification" (context of justification), but rather placed within the scope of the "discovery" (context of discovery), which gives a religious vision for science and technology (Tyoso, 1999:202). Fourth, it married the ability of rational reasoning (the power of reasoning) with the ability intuitive acuity (taste) in the search process and knowledge transfer. Or balancing the potential use of the right brain (intuitive / taste) and the potential of the left brain (rational logic). So it will not give birth to scientists who are split personality.

In the context of the State Islamic Universities (especially UIN/IAIN/STAIN), cultural strategy above is supported by the policy of "IAIN/STAIN with" Wider Mandate or even the State Islamic University (as in IAIN Syarif Hidayatullah Jakarta and IAIN Sunan Kalijaga Yogyakarta and other UIN), is a golden opportunity to respond to various demands and challenges of science and technology development at the top. Only in internal circles IAIN/STAIN themselves are still many people who doubt and worrisome, even suspecting the presence of "common courses" is this concern is well-grounded, because in reality the existence of several public colleges the nuances of Islam, which also developed the faculties/departments/study the science of Islam, however tend to be suppressed and marginalized by the faculties/departments/programs of general studies. These internal challenges that must be resolved (Muhaimin, 2004:267). 
Among IAIN/STAIN, real cultural strategies above are supported by their strong traditional roots, ranging from problems which are symbolic to the substantial nature. Symbolic aspect among others, indicated by the imperative of faculty, staff, and students who have to dress Islamically. Substantial aspects indicated by the tradition of the study of al-ulum al-naqliyyah relatively prominent than others. On the other hand, the moralspiritual sensitivity among many academicians of IAIN/STAIN not to get caught in the downtrodden and marginalized in the study of al'ulum al-naqliyyah and al'ulum al-'aqliyyah patchy.

Furthermore, the presence of the State Islamic Universities (especially UIN/IAIN/STAIN) in Indonesia is expected to become a pioneer in the creation of national integrity with views inclusive, including internally pioneered the creation of Ukhumwah Islamiyah in a broad sense, in the sense of being able to form human piety personal and social piety once. Personal piety implies a good Muslim, which has the scientific commitment to improve, enhance and develop the potential and creativity itself, while improving the quality of faith and piety in a sustainable manner. While the meaning of a creative piety that have concern to relate harmoniously with the social environment and at the same time is able to take responsibility for the development of society, or has the advantage of participatory fortified by the high quality of faith and piety to Allah (Muhaimin, 2004:269).

Overall exposure to the above confirms that it is up to the great expectations of the State Islamic Universities, in particular UIN/IAIN/STAIN in Indonesia in order initiated and pioneered the development of science and technology which is based on religious morals. It underlines the need UIN/IAIN/STAIN on operational plains constructed so that graduates are capable of acting throughout life and in all areas of expertise, as well as being on all levels of life and expertise. In a sense, in order to graduate UIN/IAIN/STAIN able to take part in any forum, it is necessary to develop areas of broader task, which includes the preparation of candidates for the clergy/religious leaders, technologists, 
psychologists, cultural/writers, economists, sociologists, scientists and others. Not only graduates who can say "ob my God" when fascination with the findings of science and technology, or just be able to say "Astaghfirullab" when the findings of science and technology create havoc.

\section{Conclusion}

In fact, it must be recognized that in the debate about Islam and this science and technology, intellectual engagement Indonesia generally very little, though also does not mean no one responds to this idea. In fact, the response made in recent years in our country is no longer solely in the form of discourse, but already at the implementation level. The rise of Islamic economy, Islamic banking, Islamic psychology, would not be separated from the product idea of Islamization of science.

Likewise, a change of IAIN Yogyakarta and Jakarta and STAIN Malang became UIN (as well as other UIN), which seeks to do the integration between Islam and science and to eliminate the dichotomy of science that has made Muslims excluded from the arena of science, it seems also born of awareness the existence of a very close relationship between Islamic science and technology.

It is fortunate that Ghirah to return to Islam prevalent among Muslims and awareness to retake control of civilization and fill it with Islamic values (human) is also firmly entrenched, but it will only be counterproductive if they are not based on an understanding of the paradigm of Islamic scholarship clear, namely the paradigm that is rooted in philosophy, epistemology and metaphysics prevailing in Islam.

As a final note on the exposure that has been said above, we can conclude some of the following:

First, there is awareness of the massif will backwardness of Muslims and the importance of mastering science and technology in an attempt to regain the glory of Islam. It would be a very good capital base for the people in the effort to rebuild the rule of science is an indicator of the progress of civilization. 
Secondly, there are differing opinions about Muslim intellectuals towards science and technology. Some see that science is neutral so it could be applied universally, others, and this is presumably more acceptable, that science is not neutral, it is loaded with a value of the Formulator, hence a critical stance toward Western science should be done.

Thirdly, in the context of the locality Indonesia, the State Islamic Universities seen to have great creative potential and contribute to the realization of such omission, plus the appearance of concrete solutions that can be taken together. Of course everything is done with the mirror to the past glories and tragedies of Muslims (as described above). In an effort to build human resources of science and technology-minded Muslim Indonesia, mainly driven by the State Islamic Universities, the necessary strategic steps called for by Hidayat Syarief as "cultural strategy". The cultural strategy is supported by a number of potential. Shows such a policy of "IAIN/STAIN" (with a wider mandate) or even the State Islamic University (as in IAIN Syarif Hidayatullah Jakarta and IAIN Sunan Kalijaga), which is a golden opportunity to respond to various demands and challenges of science and technology development above.

\section{Bibliography}

Abduh, Syekh Muhammad. Ilmu dan Peradaban menurut Islam dan Kristen, ter. Mahyiddin Syaf \& A. Bakar Usman. Bandung: Diponegoro, 1978.

Akdogan, Cemil. "Asal-usul Sains Modern dan Kontribusi Islam”, Islamia, 4 (Januari-Maret, 2005).

al-Attas, Syed M. Naquib. Islam and Secularism. Kuala Lumpur: ABIM, 1978.

Bagir, Zainal Abidin. "Pergolakan Pemikiran di Bidang Ilmu Pengetahuan", dalam Ensiklopedi Tematis Dunia Islam, ed. Taufik Abdullah et al. Jakarta: Ichtiar Baru van Hoeve, 2002. 
Bucaille, Maurice. Asal Usul Manusia Menurut Bibel, Al Qur'an dan Sains, ter. Rahmani Astuti. Bandung: Mizan, 1998.

Esposito, John L. Ensiklopedi Oxford Dunia Islam Modern, 5, ter. Jarot Wahyudi et al. Bandung: Mizan, 2001.

al-Faruqi, Ismail Raji. Islamization of Knowledge: General Principle and Workplan. Washington: IIT, 1982.

Hitti, Philip K. Dunia Arab: Sejarah Ringkas, ter. U.Hutagalung dan O.D.P. Sihombing. Bandung: t.p., t.t.

Hitti, Philip K. History of the Arabs. London: Mac. Millan dan co.Ltd, 1964.

Hoodbhoy, Pervez. Islam and Science: Religious Orthodoxy and the Battle for Rationality. London: Zed Books, 1991.

Landau, Rom. The Arab Heritage of Western Civilization. New York: t.p., 1962.

Madjid, Nurcholish. Kaki Langit Peradaban Islam. Jakarta: Paramadina, 1997.

Muhaimin. Wacana Pengembangan Pendidikan Islam. Yogyakarta: Pustaka Pelajar, 2004.

Nasr, Seyyed Hossein. Knowledge and the Sacred. New York: Crossroad, 1989.

Nasution, Harun. Islam Rasional. Bandung: Mizan, 1996.

Qadir, C.A. Philosophy and Science in the Islamic World. London: Routledge, 1988.

Rahman Fazlur, "Islamisasi Ilmu Sebuah Respon", dalam Ulumul Qur'an, 4 (1992).

Rahman, Fazlur. "Islamization of Knowledge: A Response", in American Journal of Islamic Social Sciences, 5 (1988);

Risler, Jacques C. La Civilization Arabe. Paris: Payot, 1955.

Sardar, Ziauddin. Exploration in Islamic Science. London: Mansell, 1989.

Sharif, M.M. A History of Muslim Philosophy. Wiesbadan, t.p., 1963.

Syarief, Hidayat. "Pembangunan Sumber Daya Manusia

Berwawasan IPTEK dan IMTAK" dalam Nurcholish Madjid et.el., Dinamika Pemikiran Islam di Perguruan Tinggi: Wacana tentang Pendidikan Agama Islam. Jakarta: Logos Wacana Ilmu, 1999. 
Tilaar, H.A.R. Paradigma Baru Pendidikan Nasional. Jakarta: Rineka Cipta, 2000.

Tyoso, Boma Wilkan. "Masalah Dosen Pendidikan Agama Islam di Universitas Gadjah Mada" dalam Nurcholish Madjid et.al., Dinamika Pemikiran Islam di Perguruan Tinggi. Jakarta: Logos Wacana Ilmu, 1999.

Umam, Fawaizul. "Sejarah Yang Terabaikan: Fakta Seputar Kontribusi Islam Terhadap Barat" dalam Al-Afkar Jurnal Dialogis Ilmu-Ilmu Ushuludin IAIN Sunan Ampel Surabaya, IV ( Juli-Desember 2001), 1-24.

Watt, W. Montgomery. The Influence of Islam on Medieval Europe. Edinburgh: Edinburgh University Press, 1994.

www.nature.com. diakses pada 1 Februari 2007.

Yakin, Nurul. "Revitalisasi Pendidikan Formal dan Nonformal dalam Meningkatkan Kualitas SDM NTB", makalah tidak diterbitkan, disampaikan dalam Seminar Pendidikan di AULA Kantor Gubernur NTB: "Keterpaduan Penyelenggaraan Pendidikan Formal dan Nonformal dalam Rangka Peningkatan SDM NTB", Sabtu, 22 Maret 2008, 1.

Zarkasyi, Hamid Fahmy. "Worldview Sebagai Asas Epistemologi Islam," Islamia, 5 (April-Juni 2005). 